\title{
The Role of Relationship Marketing Quality on Customer Loyalty Retention of Private Banking Product
}

\author{
I Wayan Jaman Adi Putra* \\ Departement of Management, Faculty of Economics, Universitas Negeri Malang, Indonesia
}

*Corresponding Author: I Wayan Jaman Adi Putra, Departement of Management, Faculty of Economics, Universitas Negeri Malang, Indonesia

\begin{abstract}
The objectives of the research are to discover the following points: (1) the situation of relationship marketing quality (financial, social, and customization bonds), and customer loyalty of BNI private banking; (2) the effect of relationship marketing quality on the customers loyalty. The sources of data are all customers of BNI Prima product at each branch offices of BNI bank which offered by BNI Prima product in marketing area of East Java. The election of 144 respondents that are planned uses simple random sampling technique and allocated proportionally, the methods of collecting data are questionnaire, interview, and slider of document. The methods of analysis are: (1) descriptive analysis; and (2) hypothesis testing by Structural Equation Modeling (SEM).The result of descriptive analysis are: (1) wholistically, the level of relationship marketing quality (financial, social, and customization bonds) is very high effectiveness category, but dissatisfied category; (2) wholistically, the level of customer loyalty to BNI Private Banking is quite high category;(3) the results of hypothesis testing is the relationship marketing quality (financial, social, and customization bonds) performance influence positively and significantly on the customers' loyalty.
\end{abstract}

Keywords: Relationship Marketing Quality, Customers' Loyalty, Private Banking Product.

\section{INTRODUCTION}

Instead of using mix marketing in satisfying customers, building and maintaining customers' loyalty, banks use relationship marketing to acquire, maintain, and enhance customers' loyalty over the long term period. Customers classified as rich, outstanding service quality alone is not enough anymore. Therefore, customer satisfaction should be increased to the level of sensation, even got into a solution is solving the problem because most of the customers belonging to rich people who ask very customized service and very personalized. Most banking practitioners agree that in the future, cannel and customer relationship management will become a reference compete in the consumer banking market which is really interesting to work with, while the prize just a sweetener to attract as many new customers.

Getting new customers in relationship marketing is the first step to implement the marketing process. Boone \& Kurtz (2002) stated that: "Relationship marketing is the development, growth, and maintenance of long-term, cost-effective relationship with individual customers, suppliers, employees, and other partners for mutual benefit." Relationship marketing is marketing to build, improve and maintain relationship in the long term, cost effective relationship with a customer, supplier, employee and other business partners for mutual benefit. Relationship marketing aimed at improving corporate profits by maintaining existing customers and increase customer loyalty as a relationship marketing more lucrative than marketing a single transaction. McDonald and Payne (1996) stated that: "Relationship marketing is more profitable than one of the transaction." Furthermore, Zeithaml and Bitner (2000) states: "Relationship marketing essentially represents a paradigm shift within marketing away from an acquisitions / transaction focus toward a retention / relationship focus."Relationship marketing also called retention marketing as a marketing strategy to retain the existing customers.

Relationship marketing is important for a bank because customers are now less loyal than the days of the past, because some of the main factors that arise. "That customers today are less loyal than in the past, due to six forses: (1) the abundance of choice, (2) availability, (3) entitlement (consumers repeatedly ask" what have you done for me lately? "), (4) commoditization (most products or services appear to be similar (5) insecurity (customers' financial problems reduce loyalty), and (6) time 
scarcity (not enough time to be loyal)."Schiffman and Kanuk (2000). Consequently, relationship marketing for customers is to maintain customers becomes an important part of the marketing strategy of a bank now. the marketing of products of banking services has now shifted from marketing oriented transactions (transaction marketing) that focus on the purpose of increasing profits by increasing new customers and volume sales to increase market share, has turned into a marketingoriented relationship lifetime value of the customer (customer lifetime value). Boone \& Kurtz (2002) stated that:"Relationship marketing gives a company new opportunities to gain a competitive edge by moving customers up a loyalty hierarchy from new customers to regular purchasers, then to loyal supporters of company and its goods and services, and finally to advocates who not only buy the company's products but recommend them to others."

The goal of this research is to determine the following points: (1) the state of relationship marketing quality (financial bonding, social bonding, customization bonding) perceived customers, and the level of customer loyalty;(2) the amount of the role of marketing quality relationship (financial bonding, social bonding, customization bonding) are perceived can maintain customers' loyalty.

\section{THEORETICAL FRAMEWORK}

\subsection{Relationship Marketing Quality}

Relationship Marketing Quality (RMQ) with customers is a bond or connection between a bank (company) and its customers in the form of relationship business or exchange (exchange relationship) which can include benefits: emotional, social, and psychological and financial, Banks can implement some of the strategies and tactics or marketing programs relationship with customers. Zeithaml and Bitner (2000) stated that: "the specific strategies and tactics used by firms to build relationships and tie customers closer to the firm. Fourtypes of retention tactics idea: financial bonds, social bonds, customization bonds, structural bonds. "This study simply select the application program relationship customers: financial bonds, social bonds, and customization bonds only in accordance with the ability of Bank BNI in implementing relationship marketing in marketing BNI Private Banking product, Putra(2016). Relationship marketing quality satisfied customers can strengthen and improve relationship customer with the bank in the long term.

Relationship marketing gives an opportunity for a company to gain a competitive advantage by moving to the top on a hierarchy of the loyalty of new customers into buyers regularly, and then become loyal supporters for the bank and its products, and eventually became an advocate who not only buy bank products but also encourage the bank concerned or recommend to others. By converting into a loyal customer, the bank generate repeat purchases. The maintenance cost of existing clients to be cheaper than the cost of acquiring new customers and loyal customers is someone who is profitable for banks.

\subsection{Customers Loyalty}

Banks that have Loyal Customers (CL) give an influence on the performance of a bank such as the level of growth in sales and profits of the company. Lamb et al (1999) stated: "companies benefit from repeat sales and referrals that lead to increases in market share and profits, costs fall because it is less expensive to serve than to attract the exiting customers' to a new ones". However, customers' loyalty cannot be guaranteed as a source of income for a bank customer loyalty only lasts forever."Loyal customer can mean to a firm: a consistent source of revenues over a pride of many years. It will only continue as long as the customer feels that he or she is receiving better value (including superior quality relative to price) than could be obtained by switching to another supplier." Lovelock and Wright, (2002).

Customers' loyalty is a deep commitment to subscribe or buy back an item or service consistently in the future. Although situational influences and marketing efforts could potentially cause the behavior of customers switching to competitors' products. Oliver (1997) states: "Customer loyalty is a deeply held commitment to rebuy or repatronize a preferred product or service consistently in the future. Despite situational influences and marketing Efforts having the potential to cause switching behavior. "The same opinion was also expressed by Zikmund et al (2003) which states:" The term customer loyalty Refers to a customer's commitment or attachment to a brand, store, manufacture, service provider, or other entity on favorable attitudes and behavioral responses, such as repeat purchases. "customer loyalty is also a commitment to the customer or to love a brand, stores, manufacturers, service providers or something else with a pleasant attitude and response behaves like a repeat purchase, customer's loyalty is one that is emotional rather than rational, because loyalty is based on 
emotional stronger than loyalty based on rational considerations. Lucas (2005) states: "Customer loyalty is an emotional rather than a rational thing. It is typically based on customer interest in maintaining a relationship with your organization. Often, customer interest is created and maintained through one or more positive experiences which leads to a relationship ". Customer loyalty usually merdasarkan on interest or desire to retain customers of a relationship with a bank. Often, customers' interest is created and maintained by one or more positive experience is certainly there for a relationship. "A loyal customer is one who: (1) makes regular repeat purchases; (2) purchases across product and service lines; (3) refer others; and (4) demonstrates an immunity to the pull of the competition."Griffin (1997). Another opinion about customer loyalty proposed by Hill and Akexander (2003) which stated: "Loyalty is not a simple concept but a complex one involving varying levels of customer commitment to your organization. The levels of customer loyalty or mommitment: customer retention, share of wallet, recommendation, accessbility of alternatives, attraction of alternatives. "Customer loyalty can be grouped into two: consumers' behavior and the attitude of the customers' attitude. The behavior of loyal customers is reflected in: (1) make a repeating purchases, (2) make purchases across product and service lines, (3) the allocation or distribution of the proportion of funds (share of wallet) customers. Customers's attitude include (1) discuss anything positive about the bank to others (words of mouth), (2) invite others (refers others), (3) showed an immunity to the pull of the competition), (4) provide feedback to the company as a business partner. Those seventh loyalty indicators are used in this study to measure the level of customers' loyalty on BNI pivate banking products.

\subsection{The Relationship Marketing Quality with Customers' Loyalty}

In relationship marketing, customer loyalty has a serious attention. Gummesson (2001) stated that: "In relationship marketing, customer loyalty--- is especially emphasized. In the loyalty ladder, the lowest rung is the contact with a prospect that hopefully turns into a customer and a first purchase. Recurrent customers are clients; Reviews those have come back and a long-term relationship is in the making."The bank applies the marketing mix and relationship marketing on accordance with the target market segment served the bank to obtain, maintain, and improve customer loyalty."'Lovelock and Wirtz (2004) stated:"foundation of building customer loyalty: (1) Segmenting the market to suit the needs of customers with the ability of banks, selected the goal to get the customer in accordance with the value of core services, managing customer base through a bonding effective service, and deliver a quality service; (2) then, to create bonds of loyalty with: building bonds at a higher level, deepen relationship, and reward loyalty; (3) Reduce the driving destabilizing customer loyalty by: diagnosing the shaker, customers' loyalty to look for the important driving shaker customer loyalty, and handling complain effectively, and increase switching costs."

The quality level of customer relationship marketing affect customer loyalty proposed by Grönroos (2001) which stated that: "the strength of a relationship of make customers loyal." The same opinion was also expressed by Donaldson and O'Toole (2002) stated that:"True loyalty comes from a strong brand and the relevant market proposition combined with superior products, services and delivery. Deeper, long-lasting and more profitable relationships performance."Mohammed et al (2002) stated: "In as few word as possible, one-to-one relationship is based on the simple idea of treating different customers differently. Companies initiate one-to-one relationship programs in oder to create more loyal, profitable customers, and to protect reviews their unit margins from erosion."

The retention process (maintaining) the customer actually started since the acquisition new customers, followed by relationship customers. Zikmund et al (2003) states: "While getting customers is fundamental to business success, keeping customers is more impotent. Successful firms work to build long-term relationship with Reviews their customers."The bank is a bank successful work by building relationship with customers. Grönroos (2001) also states: "The customer's behavior is dependent on is feelings of loyalty and commitment to the firm. However, there also other factors that have an impact on behavior. These are bonds which exist between the customer and the service provider. "

The purpose of the customer affinity is resulting in loyal customers and a commitment to the bank. Zikmund et al (2003) stated that: "The company goal may be to develop a one-to-one, or customized, approach to building loyalty. Frequently, organization attempt to recognize individuals, cultivate relationships through interactions that delight the customer, and develop feelings of trust within the community over time."Blattberg et al (2001) stated that:"There are seven determinants of customer retention: (1) customer expextation versus the delivered quality of the product or service, (2) value, 
(3) product uniqueness and suitability, (4) loyalty mechanisms, (5) ease of purchase (availability, convenience), (6) customer service, (7) ease of exit."The process of building customer relationship is considered positive (positive regard), meaning that customers feel valued by the bank with whom they do business. Unruh (1996) stated: "The company has rewarding....offering Reviews their customers' incentives to establish and maintain mutually benefical relationship. Although rewards are often reviled as short-term fads, they can and do build customer loyalty."All companies willing to reward them for loyal customers in the long term. Although often only for short-term goals, awarding the customer can build customer loyalty.

Building relationship by providing financial advisors also produces its share of wallet (share of wallet) which means allocating funds higher. Barnes (2001) declared the results to be obtained by the bank from relationship customers a powerful and familiar comes from several sources: (1) increase the likelihood, the customer will remain a customer, (2) the length of time the customer will remain a customer, (3) customer will give a percentage (allocation) business (share of wallet) that is greater in the bank, and (4) the greater likelihood that customers would recommend the bank to their friends and family members. Storbacka and Lehtinen (2001) stated that: "when a customer relationship is strong, there are significantly more opportunities to increase of the share of a customer's mind, emotions, and wallet a company can win, the stronger the loyalty generally is." Next, Hitt et al (2005) stated that: "The firm's relationship with its customers are strengthened when it superior value delivery. Delivering superior value often results in increased loyalty from customers to the firm providing it. "Linkage customers and banks rose when delivering superior value to its customers. Delivery of superior value often results in customer loyalty in the banks that serve them. Companies should put forth enough investment in building quality relationships with loyal or disloyal potentially customers," Ndubisi(2004).

\section{RESEARCH METHOD}

The design of this study uses descriptive survey and an explanatory survey. Descriptive survey method is used to discover and describe the circumstances relationship perceived quality of customer marketing and customer loyalty levels. While the survey method used explanatory variables to explain the role of marketing quality relationship the level of customer loyalty through a hypothesis based on the data in the field (empirical). The unit of analysis in this study is that customers' individual product BNI Private Banking in the region of East Java marketing. According to the statistical rules, the determination of sample size of 144 customers as respondents, rated can describe the characteristics of the population. Techniques to determine the respondents using simple random sampling technique. The data collection is done by using a questionnaire submitted to the customer selected as respondents. Analysis of the data used in the study are: (1) descriptive analysis and (2) Structural Equation Modeling (SEM).

\section{RESEARCH FINDINGS}

The state of the perceived quality of customer relationship marketing both overall and by each sub variable are presented in Table 1.

Table1. Circumstances of Relationship Marketing Quality of BNI Private Banking Customers

\begin{tabular}{|l|c|c|c|c|c|c|}
\hline $\begin{array}{c}\text { Relationship } \\
\text { Marketing Quality } \\
\text { Indicators }\end{array}$ & $\begin{array}{c}\text { Perceived } \\
\text { Relationship } \\
\text { Marketing Quality } \\
\text { (P) }\end{array}$ & $\begin{array}{c}\text { Expected } \\
\text { Relationship } \\
\text { Marketing } \\
\text { (E) }\end{array}$ & $\begin{array}{c}\text { Customer } \\
\text { Relationship } \\
\text { Marketing Quality } \\
\text { (P/E) }\end{array}$ & \multicolumn{2}{|c|}{ Conclusion } \\
\cline { 2 - 7 } & Score & $\begin{array}{c}\text { Score } \\
\text { Effective } \\
\text { ness }\end{array}$ & Category & $\begin{array}{c}\text { Percentage } \\
\text { (Gap) }\end{array}$ & Satisfaction \\
\hline Financial bonds & 2157 & 2467 & 0,8743 & Very high & $-12,57$ & Less satisfied \\
\hline Social bonds & 2060 & 2394 & 0,8605 & Very high & $-13,95$ & Less satisfied \\
\hline Customizationbonds & 2667 & 3021 & 0,8828 & Very high & $-11,72$ & Less satisfied \\
\hline Total & $\mathbf{6 8 8 4}$ & $\mathbf{7 8 8 2}$ & $\mathbf{0 , 8 7 3 4}$ & Very high & $\mathbf{- 1 2 , 6 6}$ & Less satisfied \\
\hline
\end{tabular}

Source: processed from an ordinal data $(n=144)$.

Based on Table 1 above, we can see the level of perceived relationship marketing quality for BNI Private banking customers overall (total) are in the category of very high at 0.8734 or $87.34 \%$ (ratio of $\mathrm{P}$ to $\mathrm{E}$ ). This proves that the Bank BNI has been able to achieve the level of effectiveness of perceived relationship marketing quality of BNI Private banking customers at a very high level. Nonetheless, Bank BNI has not been able to provide quality relationship marketing customer satisfactory because 
of the large value of the ratio P/E of quality relationship marketing customers less than one $(\mathrm{P} / \mathrm{E}<1)$, in other words, there are still gaps (gap) between what expected (E) with what is perceived (P) customer at $-12.66 \%$, which also means the quality of customer marketing in the category relationship not satisfy the customer.

To measure the level of customer loyalty, BNI Private banking products are used seven indicators of loyalty follows. (1) to deposit funds repeatedly (repeat saving); (2) using other types of services offered by Bank BNI (purchases across product and service lines); (3) allocation of funds storage (share of wallets); (4) telling others about the positive image of BNI Private banking products (words of mouth); (5) invite others to use BNI Private banking products (refers to others); (6) Shows immune from the pull of competing banks BNI (demonstrated an immunity to the pull of the competition); (7) Provide feedback to the BNI bank as a business partner. Scoring the level of customer loyalty BNI Private banking products both overall and per indicators presented in Table 2.

Table2. Circumstances of Customer Loyalty Rate for BNI Private banking

\begin{tabular}{|c|c|c|c|c|c|c|c|c|c|c|c|c|}
\hline \multirow[t]{2}{*}{ Loyalty Indicators } & \multicolumn{2}{|c|}{ Very High } & \multicolumn{2}{|c|}{ High } & \multicolumn{2}{|c|}{ Quite High } & \multicolumn{2}{|c|}{ Low } & \multirow{2}{*}{$\frac{\text { Very Low }}{\text { F }}$} & \multicolumn{2}{|c|}{ Total } & \multirow[t]{2}{*}{ Category } \\
\hline & $\mathbf{F}$ & $\%$ & $\mathbf{F}$ & $\%$ & $\mathbf{F}$ & $\%$ & $\mathbf{F}$ & $\%$ & & $\%$ & Skor & \\
\hline Repeating savings & 2 & 1,4 & 100 & 69,4 & 34 & 23,6 & 8 & 5,6 & 0 & 0,0 & 528 & High \\
\hline Cross product purchase & 7 & 4,9 & 74 & 51,4 & 37 & 25,7 & 26 & 18,1 & 0 & 0,0 & 494 & Quite high \\
\hline Saving allocation & 17 & 11,8 & 104 & 72,2 & 21 & 14,6 & 2 & 1,4 & 0 & 0,0 & 568 & High \\
\hline Refer to others & 2 & 1,4 & 44 & 30,6 & 36 & 25,0 & 62 & 43,1 & 0 & 0,0 & 418 & Quite high \\
\hline Inviting others & 2 & 1,4 & 58 & 40,3 & 56 & 38,9 & 28 & 19,4 & 0 & 0,0 & 466 & Quite high \\
\hline $\begin{array}{l}\text { Retention of not moving } \\
\text { to other banks }\end{array}$ & 4 & 2,8 & 109 & 75,7 & 11 & 7,6 & 14 & 9,7 & 6 & 4,2 & 523 & High \\
\hline $\begin{array}{l}\text { Giving feedback for the } \\
\text { bank }\end{array}$ & 0 & 0,0 & 29 & 20,1 & 59 & 41,0 & 52 & 36,1 & 4 & 2,8 & 401 & high \\
\hline
\end{tabular}

Total 3398 Quite high

Source: processed from the appendix of ordinal data $(n=144)$.

Table 2 shows the results of overall scoring (total) level of customer loyalty products BNI Private banking is in the category is quite high that with a score of 3398 which is in the range of the classification criteria between 2622-3427, but there are three important indicators of the seven indicators that show the high category ie the indicator storage, allocation and use of funds does not want to move to a bank's competitor.

Parameter estimation or measurement results for the indicator variable quality relationship marketing can be shown in the form of Table 3.

Table3. Parameter Estimation Results Variable Relationship Marketing Quality

\begin{tabular}{|l|c|c|c|c|c|}
\hline \multicolumn{1}{|c|}{ Parameter } & Loading Factor & $\mathbf{R}^{\mathbf{2}}$ & Error Variance & t- count & \multicolumn{1}{c|}{ Note } \\
\hline Financial bonds $\left(\mathrm{X}_{1}\right)$ & 0.7751 & 0.6008 & 0.3992 & 8.1839 & Significant \\
\hline Social bonds $\left(\mathrm{X}_{2}\right)$ & 0.7430 & 0.5520 & 0.4480 & 7.9663 & Significant \\
\hline Customizationbonds $\left(\mathrm{X}_{3}\right)$ & 0.6204 & 0.3850 & 0.6150 & 6.7612 & Significant \\
\hline Total & 2.1385 & 1.5378 & 1.4622 & & \\
\hline
\end{tabular}

Table 3 shows the three subvariable of variable quality relationship marketing has a positive coefficient and t test every subvariable shown significant results (significant) so that third subvariable of variable quality relationship marketing that they can be used to explain the latent variables marketing quality relationship perceived customer product of BNI Private Banking.

Parameter estimation or measurement results for an indicator of customer loyalty variables of BNI private Banking is shown in Table 4.

Table 4 shows that the seventh indicator of customer loyalty variable of BNI Private Banking has a positive coefficient and t test every indicator of variable customer loyalty shown significant results so the seven indicators of customer loyalty that can be used to explain the latent variable customer loyalty products BNI Private Banking.

Table4. Parameter Estimation Results Variable of Customer Loyalty

\begin{tabular}{|l|c|c|c|c|c|}
\hline \multicolumn{1}{|c|}{ Parameter } & Loading Factor & $\mathbf{R}^{\mathbf{2}}$ & Error Variance & t- count & Note \\
\hline Repeating savings $\left(\mathrm{Y}_{1}\right)$ & 0.7032 & 0.4945 & 0.5055 & 7.7913 & Significant \\
\hline Using other service products $\left(\mathrm{Y}_{2}\right)$ & 0.7068 & 0.4996 & 0.5004 & 7.8286 & Significant \\
\hline Funding allocation $\left(\mathrm{Y}_{3}\right)$ & 0.7701 & 0.5931 & 0.4069 & 8.4711 & Significant \\
\hline Refer to others $\left(\mathrm{Y}_{4}\right)$ & 0.7708 & 0.5941 & 0.4059 & 8.4779 & Significant \\
\hline
\end{tabular}




\begin{tabular}{|l|c|c|c|c|c|}
\hline Inviting others $\left(\mathrm{Y}_{5}\right)$ & 0.6226 & 0.3876 & 0.6124 & 6.9460 & Significant \\
\hline $\begin{array}{l}\text { Retention of not moving to } \\
\text { competing banks }\left(\mathrm{Y}_{6}\right)\end{array}$ & 0.6188 & 0.3829 & 0.6171 & 6.9058 & Significant \\
\hline Giving feedback to the bank $\left(\mathrm{Y}_{7}\right)$ & 0.8296 & 0.6882 & 0.3118 & 9.0397 & Significant \\
\hline Total & 5.0219 & 3.6400 & 3.3600 & & \\
\hline
\end{tabular}

Testing the hypothesis relationship marketing quality (financial bonds, social bonds, customization bonds) positive and significant impact on customer loyalty of products BNI Private Banking shown in Figure 1.

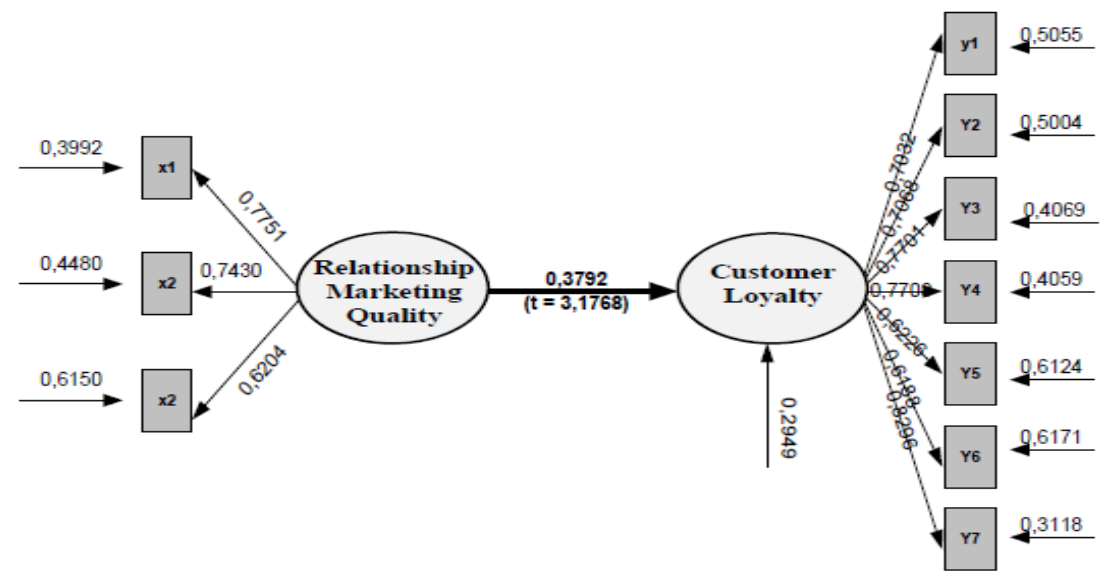

Figure1. Estimation result and path diagram for hypothesis testing

Figure 1 shows the calculation results of hypothesis testing by t-test for statistical tests influence the quality of relationship marketing which include: financial bonds, social bonds, and customization bonds on customer loyalty by 3,1768 to a significant level $(\alpha)$ study of $0.05 \mathrm{t}$ value table for a significant test limit is 1.965 . So we can conclude the role of relationship marketing quality on customer loyalty is positive and significant. The magnitude of the role of marketing quality relationship ( $\zeta 1)$ perceived customers' loyalty $(\eta 1)$ the customer is at 0,3792 , or $37.92 \%$ in order to obtain the magnitude of the direct role of variable quality on customer loyalty relationship marketing at 0.1438 or $14.38 \%$. This fact indicates that the quality of relationship marketing which include: financial bonds, social bonds, and customization bonds only act or accounted for $14.38 \%$ in explaining the formation, maintain and increase customer loyalty products BNI Private banking in the marketing area of East Java. While the remaining $85.62 \%$ is explained by other factors such as customer perceived service quality, characteristic of private customers.

\section{DISCUSSION}

All descriptive analysis showed that the level of social ties state has a greatest gap that is equal to 13.95, meaning that bank BNI in relationship marketing need to upgrade dimensions of social bonds in order to increase its marketing relationship for the customers. In addition, the performance of customer loyalty, BNI bank needs to consider indicators inform on others and indicators provide feedback to the bank that the score is relatively low compared to other indicators. Research found that customer relationship quality has a positive and significant impact on customers' loyalty, consistent (in accordance) with and supports the statement Grönroos (2001) which stated that "Customer satisfaction has a favorable effect on the strength of a relationship. Strong relationship makes customers loyal. "This theory suggests that one solution to maintain customer loyalty is with menerapaka relationship marketing strategy with a strong customer or quality. The results of this study have confirmed that the perceived quality of relationship marketing can predict customer loyalty. The fact linkages increasingly satisfied with the quality of customer marketing push relationship with higher customer loyalty in accordance with the opinion of Hitt et al (2005) which states that relationship customers with a bank or a service company will strengthen relationship marketing when these customers deliver superior quality to both sides. Submission of superior quality is very important because it often results in improved customer loyalty to a bank or service provider. The same opinion was also expressed by Donaldson and O'Toole (2002) and Bolton(1998) also states that the added value that are not visible (intangible value added) include relationship personal and historical ties can create trust and loyalty that becomes very difficult to destroy. 
BNI Bank is trying to retain and increase its customer loyalty over the long term by building strong customer relationship, due to strong customer relationship influenced by customer satisfaction. Barnes (2001) and Donaldson and O'Toole (2002) also stated that the relationship marketing with a strong customer and brings intimate reception (results) obtained bank comes from several sources: (1) increase the likelihood, the customer will remain a customer, (2) increase the length of time customers into customers, (3) the customer will give you a percentage (allocation) larger business at the bank, and (4) the greater likelihood that customers would recommend the bank to friends and family members. Another opinion expressed by Hill and Alexander (2003) and Kavitha and Palanivelu (2012)states is the result of customer retention or customer relationship quality, because the main purpose of relationship marketing customer or customer bonding is to maintain existing customers. Customer retention is the lowest form of loyalty and is a simple measurement to determine if the customer had stayed on the bank concerned or moving to a bank or services of a competitor company. The results of testing this hypothesis also supports the results of empirical research conducted by several experts, among others: Kristof, et al (2001) and Taleghani, et al (2011) reported findings that directly, preferential treatment, interpersonal communications, real appreciation justifying investment in relationship consumers. Investment in customer relationship positive effect on the quality of relationship, and subsequently the quality relationship positive effect on behavior loyalty.

Research results by Chakiso (2015) and Husnain \& Akhtar (2015) also found no positive track (positive path) of satisfaction relationship (relationship satisfaction) of the length of relationship (relationship duration) and the purpose of the purchase (purchase intention) which can be considered as an indicator of loyalty. To that end, academics and practitioners trying to treat loyal customers by concentrating on the problem: financial bonding, social bonding and customization bonding to be able to maintain the loyalty of its customers. This finding requires that the various types of customer loyalty behaviors need to bond different. The results of this study recommend that a marketing strategy relationship need diseseuaikan to the needs of each client. In addition, the findings of this study also indicate that in order to increase customer loyalty, product marketers in the bank must ensure that the client feels prioritized in service and they see minimal risk and is satisfied with the relationship. Dimensions of social ties in the field of business not only improve the relationship but also increase loyalty to the company's bank, Zeithaml and Bitner (2000).

\section{CONCLuSion}

From the results of data analysis and discussion of the research results, it can be formulated some conclusions as follows: (1) the state of the quality of the overall customer relationship marketing demonstrate the effectiveness category is very high, but considered unsatisfactory; (2) the level of achievement of the overall customer loyalty are in a quite high category; (3) the quality of customer relationship marketing perceived positive and significant impact on customers' loyalty. This suggests that the perceived quality of customer relationship marketing play a significant effect on the customers' loyalty.

\section{REFERENCES}

[1] Barnes, James G. 2001. Secrets of Customer Relationship Management.Translated by Andreas Winardi. Andi Publisger. Yogyakarta.

[2] Blattberg, Robert C., Gary Getz and Jacquelyn S. Thomas. 2001. Customer Equity. Building and Managing Relationship as Valuable Asset. Harvard Business School Publishing Corporation. USA.

[3] Boone, Louis \& David L. Kurtz. 2002. Contemporary Marketing. South - Westren Thomson Learning. Inc. Australia.

[4] Bolton, Ruth N. 1998. A Dynamic Model of the Duration of the Customer's Relationship with a Continuous Service Provider, The Role of Satisfaction. Marketing Science. 17 (1). 45-65.

[5] Chakiso, Cherinet Boke. 2015. The effect of relationship marketing on customers' loyalty (Evidence from Zemen Bank). Emerging Markets Journal.Volume 5 No 2.

[6] Donaldson, Bill and Tom O’Tolle. 2002. Strategic Market Relationship. From Strategy to Implementation. John Willy \& Sons. Ltd. Baffins Lane.

[7] Griffin, Jill. 1997. Customer Loyalty, How To Earn It, How to Keep It. Lexington Books. New York.

[8] Gronroos, Christian. 2001. Service Management and Marketing, A Customer Relationship Management Approach. John Wiley \& Son. New York.

[9] Gummesson, Evert. 2001. Total relationship Marketing. Butterworth Heinemann. Oxford. 
[10] Hill, Nigel. \& Jim Alexander. 2003. Handbook For Measuring Customer Satisfaction and Loyalty. Invinity Book. A Maya Gower Imprint. New Delhi.

[11] Hitt, Michael A., R. Duane Ireland, Robert E. Hoskisson. 2005. Strategic Management, Competitive and Globalization. Thomson South-Western. Australia.

[12] Husnain, Mudassir \& M Waheed Akhtar. 2015. Relationship Marketing and Customer Loyalty: Evidence fromBanking Sector in Pakistan. Global Journal of Management and Business Research:E Marketing. Volume 15 Issue 10 Version 1.0

[13] Kristof, De Wuff; Gaby Odekerken Sdhroder and Dawn Iacobucci. 2001. Investment in Customer Relationships: A Cross-Country and Cross-Industry Exploration. Journal of Marketing. Vol. 65 (Oktober). 33-50.

[14] Kavitha, K.S. and P. Palanivelu. 2012. Customer Satisfaction:CRM in Canara Bank.SCMS Journal of Indian Man a g e m e $n t$, July - September, 99-108

[15] Lamb Jr, Charles W., Joseph F. Hair Jr., Carl McDaniel. 1999. Essentials of Marketing. SouthWesternCollege Publishing. Cincinnati. Ohio.

[16] Lovelockand Jochen Wirtz. 2004. Services Marketing, People, Technology, Strategy. Prentice-Hill Pearson Education International Inc. New Jersey.

[17] Lovelock, Christopher H. and Lauren Wright. 2002. Principle of Service Marketing and Management. Prentice Hill Pearson Education International Inc. New Jersey.

[18] Lucas, Robert W. 2005. Customer Service, Building Successful Skills for the Twenty-First Century. Mcgraw-Hill Irwin. Boston.

[19] McDonald, Malcolm and Adrian Payne. 1996. Marketing Planning For Service. Butterworth Heinemann. Oxford.

[20] Mohammed, Rafi; Robert J. Fisher, Bernard J. Jaworski, Aileen M. Cahill. 2002. Internet Marketing, Building Anvantage in a Networked Economy. International Edition. McGraw-Hill Irwin Marketspace. Boston.

[21] Ndubisi, N.O. 2006. Relationship Marketing and Customer Loyalty. Marketing Intelligence \& Planning, 25(1), 98-106.

[22] Oliver, Richard L.. 1997. Satisfaction. A Behavioral Perspective On The Consumer. Prentice Hall International Editions Inc. New York.

[23] Putra, I Wayan Jaman Adi. 2016. The Effect of Personal Situation and Service Quality on The Relationship Performance of BNI Personal Banking.International Journal of Marketing \& Human Resource Management (IJMHRM). Volume 7, Issue 2. 18-26

[24] Schiffman, Leon G. and Leslie Kanuk. 2000. Consumer Behavior. Prentice Hal Internasional, Inc. New Jersey.

[25] Storbacka, KAJ, Jarmo R. Lehtinen. 2001. Customer Relationship Management, Creating Competitive Advantage through Win-Win Relationship Strategies. McGraw-Hill. Boston.

[26] Taleghani, Mohammad, Shahram Gilaninia, Seyyed Javad Mousavian.2011. The Role of Relationship Marketing in Customer Orientation Process in the Banking Industry with focus on Loyalty(Case Study: Banking Industry of Iran). International Journal of Business and Social Science. Vol. 2 No. 19.

[27] Zeithaml, Valarie. A. and Mary Jo Bitner. 2000. Service Marketing, Integrating Customer Focus Across the Firm. The McGraw-Hill Companies Inc. Boston.

[28] Zikmund, William G., Raymond McLeod Jr. and Faye W. Gilbert. 2003. Customer Relationship Management, Integrating Marketing Strategy and Information Technology. John Willy \& Sons Inc. Hoboken.

[29] Unruh, James A.. 1996. Customer Mean Business, Six Steps To Building Relationship That Last. AddisonWesley Publishing Company Inc. Massachusetts.

\section{AUTHORS' BIOGRAPHY}

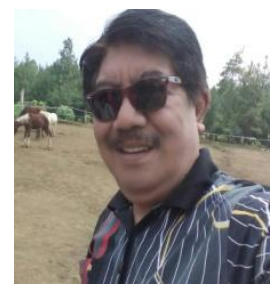

Dr. I Wayan Jaman Adi Putra was born in Bangli, Bali, Indonesia on February 8, 1954. He currently works as a lecturer at Malang State University (UM). The courses taught are Marketing Management, Service Business Management and International Marketing Management

Citation: I Wayan Jaman Adi Putra. "The Role of Relationship Marketing Quality on Customer Loyalty Retention of Private Banking Product" International Journal of Managerial Studies and Research (IJMSR), vol 6, no. 8, 2018, pp. 1-8. doi:http://dx.doi.org/10.20431/2349-0349.0608001.

Copyright: (c) 2018 Authors. This is an open-access article distributed under the terms of the Creative Commons Attribution License, which permits unrestricted use, distribution, and reproduction in any medium, provided the original author and source are credited. 